\title{
Frequency Domain Diagnostics of Transformer Insulation
}

\author{
M. Gutten ${ }^{1}$, M. Šebok ${ }^{1}$, D. Korenčiak ${ }^{1}$, P. Brnčal ${ }^{1}$, M. Kubiš ${ }^{1}$, P. Żukowski ${ }^{2}$, \\ T.N. Koltunowicz ${ }^{2}$ \\ ${ }^{1}$ University of Žilina, \\ Univerzitná 1, Žilina 010 26, Slovakia, \\ ${ }^{2}$ Lublin University of Technology, \\ Nadbystrzycka str., 38A, Lublin 20-618, Poland
}

Received 07.10.2019

Accepted for publication 18.11.2019

\begin{abstract}
The first part of paper deals with the base information about diagnostics of power transformers. In this part are presented differently insulating methods, for example method of recovery voltage method, method of polarization and depolarization currents and chromatographic analysis.

The second part of paper deals use of method of frequency domain spectroscopy for oil power transformers. This method is used in analysis insulating condition of power transformer with system of oil-paper. It was found, that the results of these tests are highly impacted by the operating temperature during the experimental measurement. Moisture and conductivity between insulating paper and oil in an insulating system are highly dependent from temperature.

In the other part, the paper presents experimental results of the frequency diagnostic measurement for a real single-phase traction transformer $110 / 27 \mathrm{kV}$ at different operating temperatures and states (with oil and without).

Finally in the last part, the paper presents comparing frequency insulating measurements among several the same single-phase transformers $110 / 27 \mathrm{kV}$.
\end{abstract}

Keywords: transformer, diagnostics, insulation, paper, oil.

DOI: $10.21122 / 2220-9506-2019-10-4-353-359$

\begin{tabular}{l} 
Aдрес для переписки: \\
P. Żukowski \\
Lublin University of Technology, \\
Nadbystrzycka str., 38A, Lublin 20-618, Poland \\
e-mail: p.zhukowski@pollub.pl \\
\hline Для цитирования: \\
M. Gutten, M. Šebok, D. Korenčiak, P. Brnčal, M. Kubiš, P. Żukowski, \\
T.N. Koltunowicz. \\
Frequency Domain Diagnostics of Transformer Insulation. \\
Приборы и методы измерений. \\
2019. - Т. 10, № 4. - С. 353-359. \\
DOI: 10.21122/2220-9506-2019-10-4-353-359
\end{tabular}

Адрес для переписки:

Lublin University of Technology,

Nadbystrzycka str., 38A, Lublin 20-618, Poland

e-mail:p.zhukowski@pollub.pl

\author{
Address for correspondence: \\ P. Żukowski \\ Lublin University of Technology, \\ Nadbystrzycka str., 38A, Lublin 20-618, Poland \\ e-mail:p.zhukowski@pollub.pl
}

For citation:

M. Gutten, M. Šebok, D. Korenčiak, P. Brnčal, M. Kubiš, P. Żukowski, T.N. Koltunowicz.

Frequency Domain Diagnostics of Transformer Insulation.

Devices and Methods of Measurements.

2019, vol. 10, no. 4, pp. 353-359.

DOI: $10.21122 / 2220-9506-2019-10-4-353-359$ 


\section{Диагностика частотной области изоляции трансформатора}

\section{М. Гуттен ${ }^{1}$, М. Шебок ${ }^{1}$, Д. Коренчяк ${ }^{1}$, П. Брнчал ${ }^{1}$, М. Кубиш $^{1}$, П. Жуковский ${ }^{2}$, Т.Н. Колтунович ${ }^{2}$}

${ }^{1}$ Жилинский университет,

ул. Университетская, 1, г. Жилина 010 26, Словакия

${ }^{2}$ Люблинский технологический университет,

ул. Надбыстриикая, 38А, Люблин 20-618, Польша

Поступила 07.10.2019

Принята к печати 18.11.2019

В первой части статьи приведены базовые сведения о методах диагностики силовых трансформаторов. В этой части представлены различные методы исследования изоляции, в частности, метод восстановления напряжения, метод токов поляризации и деполяризации и метод хроматографического анализа.

Во второй части статьи рассмотрено использование метода частотной спектроскопии для масляных силовых трансформаторов. Данный метод использован для анализа состояния изоляции силовых трансформаторов с системой масло-бумага. Определено, что на результаты такого анализа значительное влияние оказывает температура окружающей среды при проведении измерений. Влажность и проводимость между бумажной изоляцией и маслом существенно зависят от температуры.

Далее в статье приведены экспериментальные результаты диагностических частотных измерений для однофазного тягового трансформатора 110/27 кВ при различных значениях температуры окружающей среды и в различных состояниях (с маслом и без масла).

В завершающей части статьи выполнено сравнение результатов частотных измерений нескольких однотипных однофазных трансформаторов 110/27 кВ.

Ключевые слова: трансформатор, диагностика, шумоизоляция, бумага, масло.

DOI: $10.21122 / 2220-9506-2019-10-4-353-359$

\begin{tabular}{l} 
Aдрес для переписки: \\
P. Żukowski \\
Lublin University of Technology, \\
Nadbystrzycka str., 38A, Lublin 20-618, Poland \\
e-mail: p.zhukowski@pollub.pl \\
\hline Для цитирования: \\
M. Gutten, M. Šebok, D. Korenčiak, P. Brnčal, M. Kubiš, P. Żukowski, \\
T.N. Koltunowicz. \\
Frequency Domain Diagnostics of Transformer Insulation. \\
Приборы и методы измерений. \\
2019. - Т. 10, № 4. - С. 353-359. \\
DОI: $10.21122 / 2220-9506-2019-10-4-353-359$
\end{tabular}

Адрес для переписки:

Lublin University of Technology,

Nadbystrzycka str., 38A, Lublin 20-618, Poland

Для цитирования:

T.N. Koltunowicz.

Приборы и методы измерений.

DOI: $10.21122 / 2220-9506-2019-10-4-353-359$

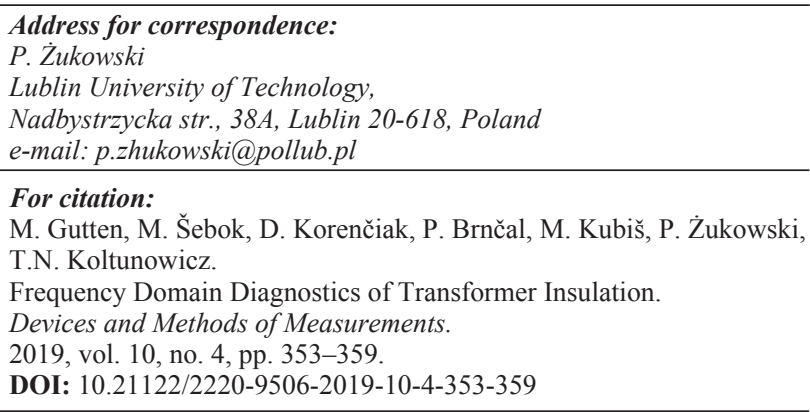




\section{Introduction}

Condition evaluation of insulating the highvoltage oil transformers, particularly of oil conductivity and paper moisture, is becoming more significant for aged power transformers and also for quality control of new equipment in the manufacturing factory. The interest for reliable and easy to use measuring and diagnostic technique drove the development of dielectric time and frequency response methods $[1,2]$.

It is necessary to know condition of transformer insulation between dielectric elements and insulating properties in operating state.

The first approach, called recovery voltage method (RVM - Figure 1), is nowadays already known. The newer two methods, polarization and depolarization currents (PDC) and frequency domain spectroscopy (FDS), demonstrated their suitability for diagnostics of transformer and are now frequently used [3].

The advantage of these methods is that it is possible to detect moisture in paper insulation and conductivity in oil of power transformers.

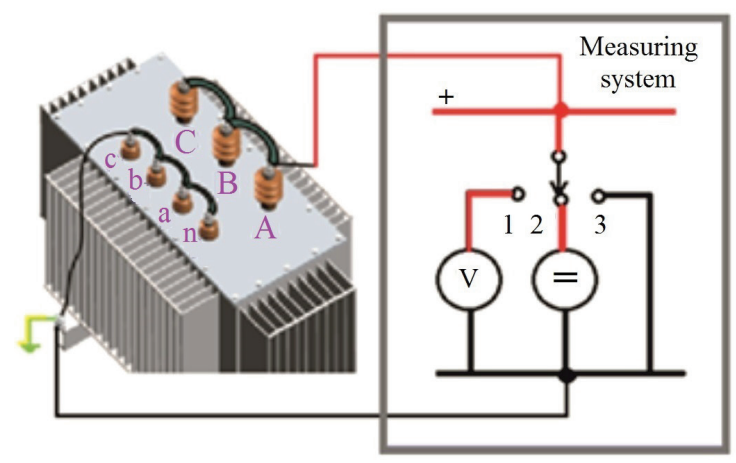

Figure 1 - Principal scheme of recovery voltage method

To prevent failure, it is necessary to analyse the chemical processes in insulating oil and paper, as well as their impact on other components of oil transformers too.

Chromatographic analysis of gases in insulating oil belongs to the physic-chemical methods using of processes that occur due to negative thermal, electrical or combined phenomena in the failure state of the machine insulation systems, which exhibit by production of gases, known as decomposition gases $[4,5]$.

These types of defects can occur at any time, and because it is an indirect method, allowing detection of gas generated, the challenge is assessed through the composition and quantity of gas, the potential severity of a fault condition of the transformer.

\section{The basic diagnostics of transformers by frequency domain spectroscopy method}

Previous research works in condition diagnostics of dialectical insulation have indicated that the frequency domain spectroscopy can the most effectively estimate deterioration in insulation of oil-paper in power transformer. Since especially the low frequencies (to $0.1 \mathrm{~Hz}$ ) reflect moisture concentration, their measurement is of outmost importance for reliable data analysis. Beside a frequency sweep, the response of a dielectric to a voltage sweep is experimentally investigated and discussed [9].

Special focus is given on a comparison of the currently available dielectric spectroscopy methods to traditional measurement techniques like dielectric dissipation factor $(\operatorname{tg} \delta)$ tests at power frequency and $0.1 \mathrm{~Hz}$, dielectric adsorption ratio and the polarization index. The traditional methods suffer from a limited time or frequency range which impedes the discrimination of specific dielectric properties. If for example increased losses appear, it is impossible to discriminate whether they are caused by the insulating oil or the cellulose paper insulation [6].

Applying a sinus frequency sweep in wide range means to measurement the dielectric responses in depending on quality transformer insulate [7].

Dielectric response of the whole insulation system in transformer depends on different factors i.e. on the properties of impregnated paper and pressboard, on the properties of oil, and on the geometrical arrangement of the system components and a correct evaluation of the measured data. In addition information is required about design of insulation system, i.e. the relative amounts of pressboard barriers and spacers in relation to the amount of oil.

For power transformers insulated oil-paper, the dielectric response consists of three components. They are the response of the cellulose insulation (paper, pressboard), the response of the oil and the interfacial polarization effect. Moisture, temperature, insulation geometry, oil conductivity and conductive aging by-products influence the dielectric response [8].

In Figure 2 is showed the dissipation factor of pressboard having $1 \%$ moisture content and oil together with the interfacial polarization effect (insulation geometry). The frequency range of $1000-10 \mathrm{~Hz}$ is dominated by the cellulose insulation, however also the measurement cables and the 
connection technique influence this region. Oil conductivity causes the steep slope at $1-0.01 \mathrm{~Hz}$. Dissolved conductive aging by-products, soot and high molecular weight acids increase the oil conductivity and thus influence this area. The interfacial polarization (insulation geometry, ratio of oil to pressboard) determines the local maximum or "hump" at $0.003 \mathrm{~Hz}$ [9].

The higher the ratio of oil to pressboard, the more dominating is this effect. Finally, the properties of the cellulose appear again at the frequencies below $0.0005 \mathrm{~Hz}$, here reflecting moisture, the manufacturing process and low molecular weight acids. The frequency limits correspond to Figure 2, but will vary in a wide range with moisture, oil conductivity, insulation geometry, temperature and amount of conductive aging byproducts. Moisture particularly increases the losses in the low frequency range of the dielectric response of pressboard. Thus, the point of inflexion on the left hand side of the area dominated by insulation geometry is required for a reliable moisture determination $[9,10]$.

Method FDS is mainly used for oil-paper insulation; it can also be used for dry transformers or high-voltage equipment with ferrofluid in magnetic field [7].

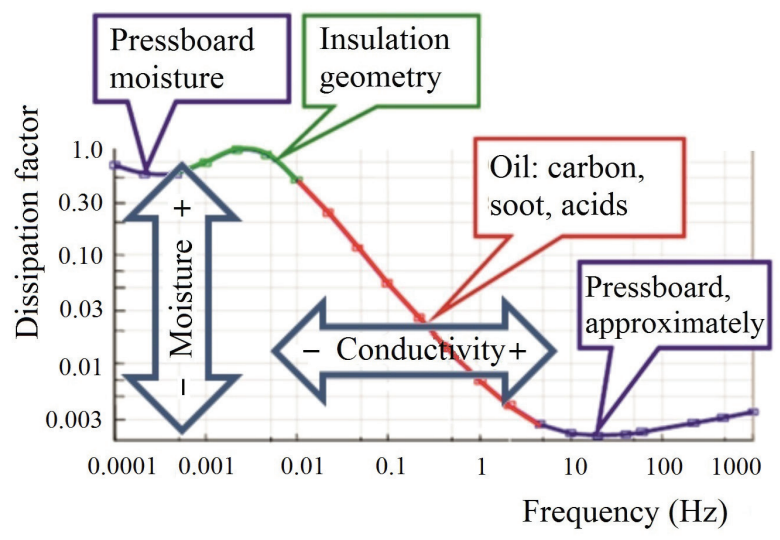

Figure 2 - Analysis of insulating transformer properties by curve of frequency domain spectroscopy method

An experimental measurement was conducted on traction single-phase transformer $110 / 27 \mathrm{kV}$, which is installed in high-voltage traction substation, for moisture analysis by dielectric spectroscopy. Measurement was conducted at temperature $+15^{\circ} \mathrm{C}$ with transformer oil and $-5{ }^{\circ} \mathrm{C}$ without oil.

For measuring was used apparatus the $M E G G E R$ $I D A X-350$ was used with the connection according to Figure 3, which works on the principle of dielectric spectroscopy (FDS method) by measuring the percentage loss factor, capacities and permittivity depending at the frequency of $1 \mathrm{kHz}$ up to $0.0001 \mathrm{~Hz}$ in the sinusoidal power supply $140 \mathrm{Vef}$.

At the first measurement with oil at $+15^{\circ} \mathrm{C}$ - the total isolation state of the transformer at $20^{\circ} \mathrm{C} / 50 \mathrm{~Hz}$ was "good state" according to percentage dissipation factor $(\operatorname{tg} \delta(\%)=0.25)$ and paper moisture was "good state" $(1.95 \%)$ by the rating graphs of measuring apparatus IDAX-350 (Figure 4). At the second measurement without oil at $-5^{\circ} \mathrm{C}$ in the comparison - the total isolation state of the transformer at $20^{\circ} \mathrm{C} / 50 \mathrm{~Hz}$ was better according to $\operatorname{tg} \delta(\%)=0.22$ and paper moisture was better too $(1.50 \%)$. Capacity of insulating system was significantly smaller (Figure 4), because transformer oil is significant part of whole insulating transformer system.

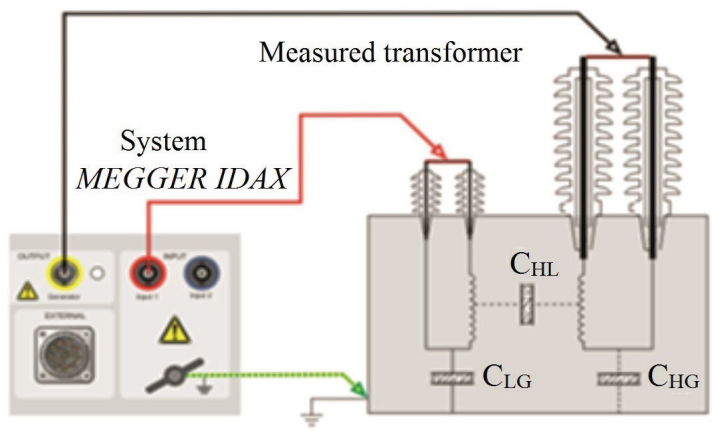

Figure 3 - Connection of the system MEGGER IDAX-350 to the measured single traction transformer $110 / 27 \mathrm{kV}$

According to Figure 4 lower temperature causes shift of curve to lower frequencies (direction to the left). This shift was the proof of the theory graph in Figure 2. Other impact was draining oil before the second measurement, because was reduced conductivity of transformer oil for zero (conductivity direction to left according to Figure 2).

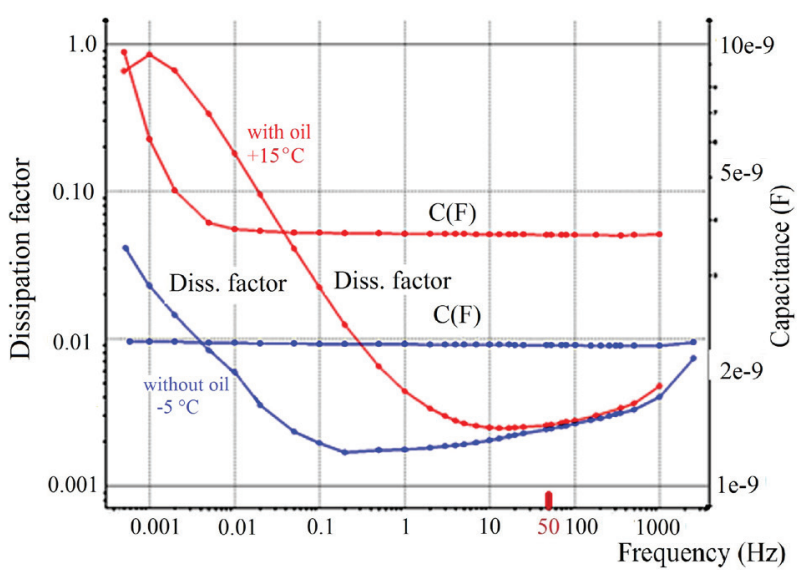

Figure 4-Measured curves of transformer at different conditions by frequency domain spectroscopy method and apparatus $I D A X-350$ 
Because measurement is performed at very low currents, it is necessary consistently linking all connections according to Figure 3. Since the device separately distinguishes measurement of individual capacities, it is necessary to thoroughly clean the location for connection of the ground conductor of the device. Poor connection results in errors in current measure-ments (and then calculated value of percentage loss factor $-\operatorname{tg} \delta(\%))$ at frequencies above $200 \mathrm{~Hz}$ (Figure 5).

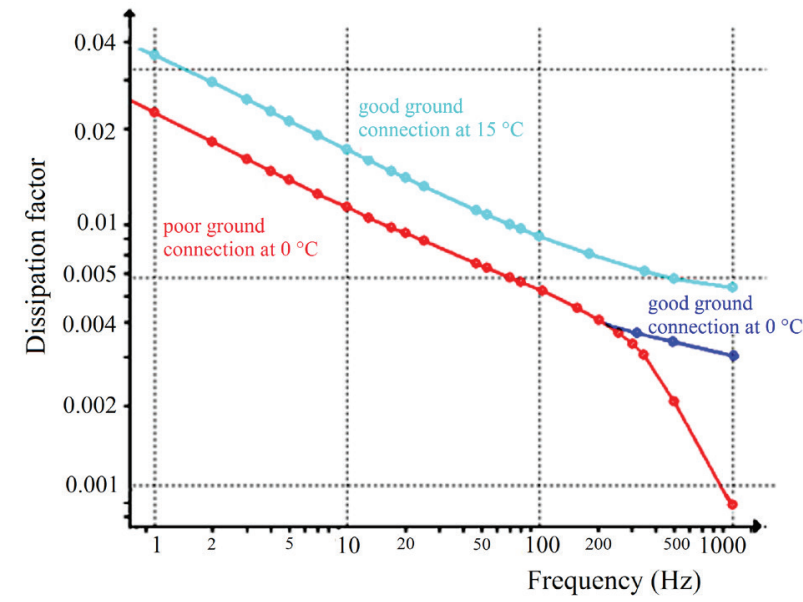

Figure 5-Measured curves of transformer at different conditions and poor/good ground by frequency domain spectroscopy method and apparatus IDAX-350

\section{Comparison of insulating state of the several same transformers}

In the part of paper it is described experimental measurement of single-phase oil autotransformers $231 / 121 / 10.6 \mathrm{kV}$, labeled $R, S, T, Q$, which are installed in power substation. It was used frequency method FDS for analysis paper moisture, conductivity in oil and total state of insulating the autotransformers.

Transformers were disconnected from the power source and measured at the ambient temperature of $16{ }^{\circ} \mathrm{C}$. All calculations at $20^{\circ} \mathrm{C}$ for the loss factor and $25^{\circ} \mathrm{C}$ for the conductivity of the transformer oil were performed by the instrument MEGGER IDAX-350.

In this method it was measured parameters - the percentage loss factor, capacities and permittivity depending on the frequency of $10 \mathrm{kHz}$ up to $1 \mathrm{mHz}$ in the sinusoidal power supply 140 Vef.

Measured real capacities and dissipation factor in frequency dependence ofmeasured autotransformer $231 / 121 / 10.6 \mathrm{kV}$, designated $R, S, T, Q$ are shown in Figures 6 and 7.

Evaluation and analysis measurement of the individual autotransformers $R, S, T, Q$ it was performed by apparatus $I D A X$ according to the rating table (Table 1).

Table 1

Basic analyses by instrument IDAX-350

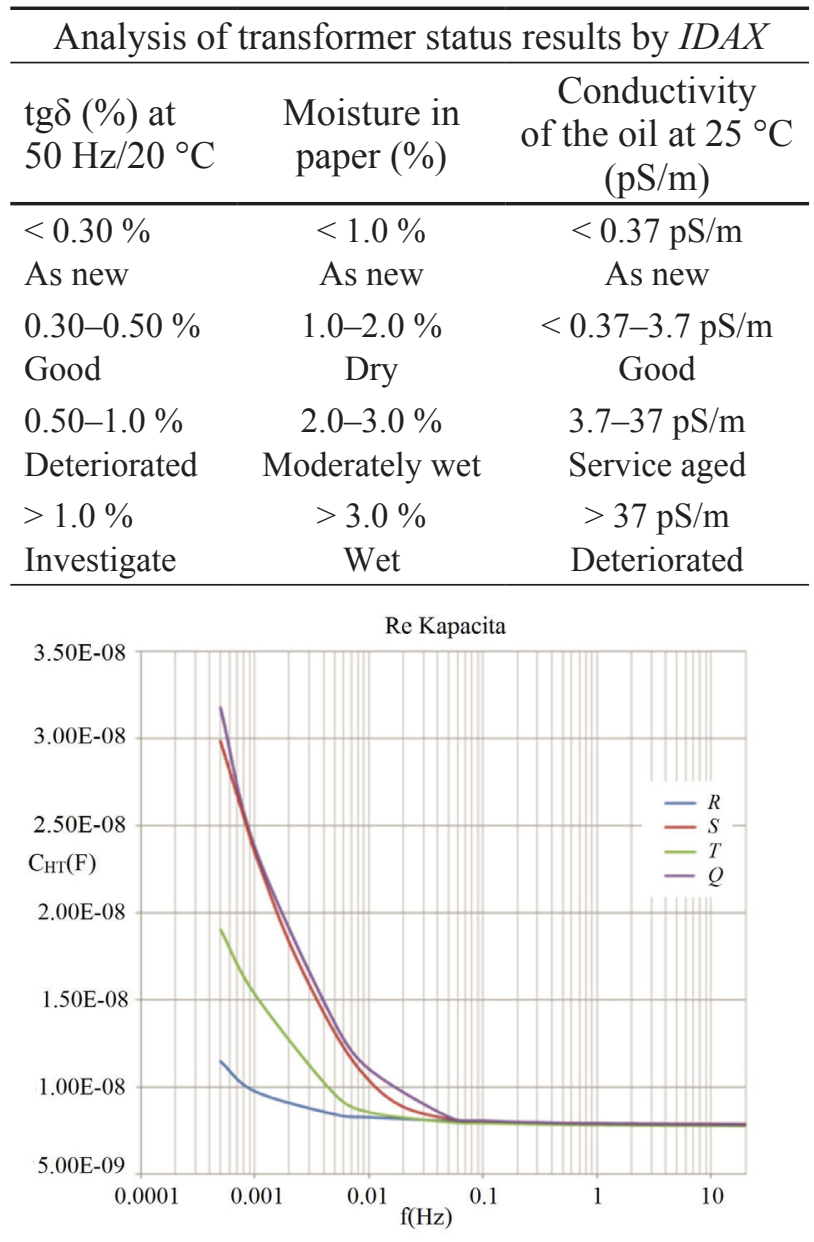

Figure 6-Comparison of measured autotransformers $R, S, T, Q$ according to the real capacities for connection high-voltage winding - tank CHT

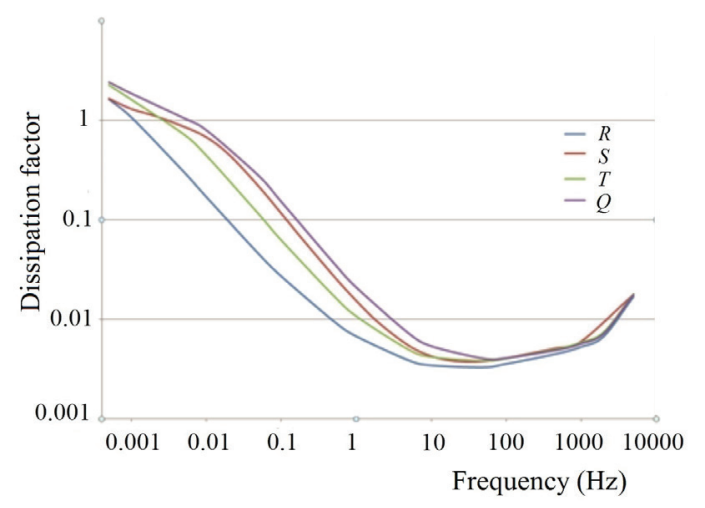

Figure 7-Comparison of measured autotransformers $R, S, T, Q$ according to the percentage dissipation factor $(\operatorname{tg} \delta(\%))$ dependence on frequency

The total isolation state at $20^{\circ} \mathrm{C} / 50 \mathrm{~Hz}$ was "good state" according to the rating table of the 
percentage dissipation factor $(\operatorname{tg} \delta(\%))$ and analysis of measured curves in Figures 6 and 7.

\section{Discussion on measured data}

At comparing these autotransformers according to Table 2, the best (lowest) value of the loss factor $\operatorname{tg} \delta(\%)$ state was represented by autotransformer $R$ with a value of $0.323 \%$, transformers $S$ and $T$ had approximately the same value of range 0.380 $0.381 \%$. Transformer $Q$ showed a slightly higher value loss factor $\operatorname{tg} \delta(\%)=0.413 \%$.

Table 2

Comparison of values for autotransformers $R, S, T, Q$

\begin{tabular}{lccc}
\hline \multicolumn{4}{c}{ Measured Results of transformers by $I D A X$} \\
\hline $\begin{array}{c}\text { Trans- } \\
\text { formers }\end{array}$ & $\begin{array}{c}\operatorname{tg} \delta(\%) \text { at } \\
50 \mathrm{~Hz} / 20^{\circ} \mathrm{C}\end{array}$ & $\begin{array}{c}\text { Moisture } \\
\text { in paper } \\
(\%)\end{array}$ & $\begin{array}{c}\text { Conductivity } \\
\text { of the oil at } \\
25^{\circ} \mathrm{C}(\mathrm{pS} / \mathrm{m})\end{array}$ \\
\hline$R$ & 0.323 & 1.9 & 0.43 \\
$S$ & 0.380 & 2.3 & 3.44 \\
$T$ & 0.381 & 2.4 & 1.36 \\
$Q$ & 0.413 & 3 & 3.28 \\
\hline
\end{tabular}

The insulation state (conductivity) of the oil at $25^{\circ} \mathrm{C}$ of the $R, S, T, Q$ autotransformers was good according to the oil conductivity table. Temperature at $25^{\circ} \mathrm{C}$ is standard for investigation and comparison other transformer oils.

At compared to these transformers, the best (lowest) value of the relative conductivity of the oil was in autotransformer $R(0.43 \mathrm{pS} / \mathrm{m})$. Transformers $S, T$ and $Q$ had oil values from 1.36 to $3.44 \mathrm{pS} / \mathrm{m}$ (Table 2).

The moisture of paper in the individual autotransformers $R, S, T, Q$ was different according to the rating table. When comparing all four transformers, the best (lowest) value of the moisture state in the paper showed the transformer $R(1.9 \%)$, which according to the evaluation table is dry. Autotransformers $S$ and $T$ had approximately the same humidity value $(2.3-2.4 \%)$, which according to the rating table is slightly humid. The last autotransformer $Q$ had the highest humidity value (3\%), which, according to the rating table, is the mild to wet boundary between the conditions.

Based on the above-mentioned analysis of the measured values, it is possible to confirm that in the autotransformer $T$, which is currently used as a reserve; most of the moisture is deposited in the paper portion of the insulation. This corresponds to an oil conductivity value of $1.36 \mathrm{pS} / \mathrm{m}$.
From the measured values, it is possible for the autotransformer $T$ to estimate that during operation, the conductivity value of the oil would be higher than that of the autotransformers $S$ and $Q$, which means that before it is put into full operation, it will be necessary to take action to reduce the moisture state of the autotransformer isolation system $T$.

The analysis further confirms that the oil in the $R$ transformer has undergone total regeneration a year before the measurement. The moisture content and oil conductivity values confirm the excellent state for the power class and the size of the autotransformers to be measured.

A slightly higher oil conductivity value in the $S$ autotransformer may indicate a higher load than the $Q$ transformer. However, the analysis revealed that the moisture content of the $Q$ transformer is highest among the other measured units, but this also means a higher susceptibility to the overcurrent failure (Figure 8).

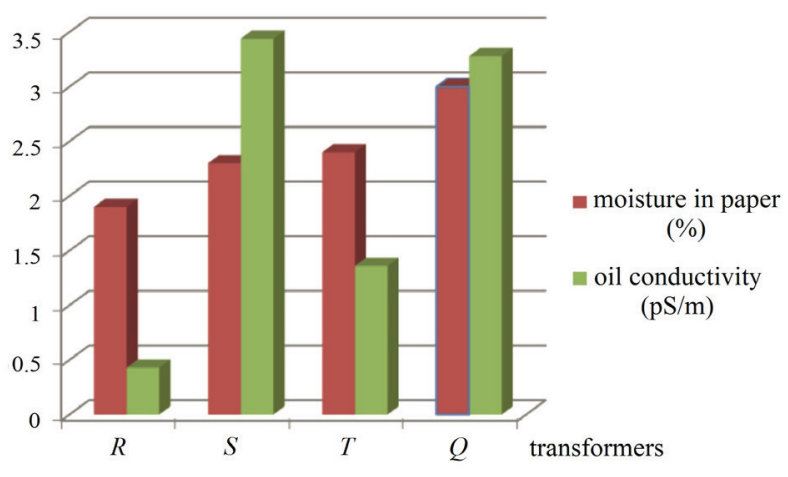

Figure 8-Table comparison of measured autotransformers $R, S, T, Q$ according to the moisture in paper (\%) and oil conductivity $(\mathrm{pS} / \mathrm{m})$

\section{Conclusion}

Experimental measurements have shown a correlation between the measured values and the operational aspects of the individual transformers. It has been shown that the biggest danger for insulation of oil transformers is their shutdown from operation (the highest moisture of paper in transformer $Q$ ).

To confirm or disprove the results of spectrum spectroscopy analysis, it would be useful to also analyze the dissolved gas in the oil of the autotransformers measured for the presence of $\mathrm{CO}_{2}$ and $\mathrm{CO}$ gases, the amount of which is mainly influenced by the cellulose quality and possible leakage of the autotransformer vessel. Despite the accuracy of the measuring device, it would be useful to compare the loss factors with the higher measuring instrument. 
This experimental analysis is determination of new set of diagnostic measured techniques for the analysis of the state of selected type of oil filled power transformers.

We will also connect physical models describing measurable parameters of partial discharge process with the effect of the degradation of insulation state of oil transformer with the increased originality and the innovation and on that basis will be created new integrated system of diagnostics with the possibility of analysis and classification of possible failures on power transformers.

\section{Acknowledgments}

This work was partially supported by the Grant Agency VEGA from the Ministry of Education of Slovak Republic under contract 1/0602/17 and by the Polish Ministry of Science and Higher Education as a science fund of the Lublin University of Technology, at the Faculty of Electrical Engineering and Computer Science, FN-28/E/ EE/2019 - Researches of electrical, magnetic, thermal and mechanical properties of modern electrotechnical and electronic materials, including nanomaterials and diagnostic of electrical devices and their components.

\section{References}

1. Bartlomiejczyk M., Gutten M., Hamacek S. A Combined TOPSIS and FA Based Strategic Analysis of Technical Condition of High Power Transformers. Advances in Electrical and Electronic Engineering, 2013, vol. 11, no. 4, pp. 251-259.

DOI: $10.15598 /$ aeee.v11i4.863
2. Brandt M. Identification failure of 3 MVA furnace transformer. International conference Diagnostic of electrical machines and insulating systems in electrical engineering. DEMISEE 2016. Papradno, SR, 2016.

DOI: 10.1109/DEMISEE.2016.7530472

3. Koch M., Krueger M., Puetter M. Advanced Insulation Diagnostic by Dielectric Spectroscopy. Omicron Electronics Austria, 2011.

4. Simko M., Chupac M. Non-destructive method of measurement of radio transmitters antenna systems. Elektronika ir elektrotechnika, 2011, vol. 107, no. 1, pp. 33-36.

5. Brandt M. Experimental measurement and analysis of frequency responses SFRA for rotating electrical machines. Elektroenergetika, 2017, Stará Lesná, SR, pp. 284-288.

6. Koch M., Tenbohlen S., Krüger M., Kraetge A. A Comparative Test and Consequent Improvements on Dielectric Response Methods. Proceedings of the XVth International Symposium on High Voltage Engineering. ISH, Ljubljana, Slovenia, 2007.

7. Koch M. Reliable Moisture Determination in Power Transformers, PhD thesis, Institute of Energy Transmission and High Voltage Engineering. University of Stuttgart, Sierke Verlag Göttingen, 2008.

8. Petras J., Kurimsky J., Balogh J., Cimbala R., Dzmura J., Dolnik B., Kolcunova I. Thermally stimulated acoustic energy shift in transformer oil. Acta Acustica United with Acustica, 2016, vol. 102, no. 1, pp. 16-22.

DOI: 10.3813 /AAA. 918920

9. Koch M., Kruger M. Moisture Determination by Improved On-Site Diagnostics. TechCon Asia Pacific, Sydney, 2008.

10. Neimanis R. On Estimation of Moisture Content in Mass Impregnated Distribution Cables. Stockholm: Royal Institute of Technology Stockholm, 2001, ISSN 1100-1593. 